\title{
Chronic intake of a high-cholesterol diet resulted in hepatic steatosis, focal nodular hyperplasia and fibrosis in non-obese mice
}

\author{
Maho Sumiyoshi ${ }^{1}$, Masahiro Sakanaka ${ }^{1}$ and Yoshiyuki Kimura ${ }^{2} *$ \\ ${ }^{1}$ Division of Functional Histology, Department of Functional Biomedicine, Graduate School of Medicine, Ehime University, \\ Shitsukawa, Toon-City, Ehime 791-0295, Japan \\ ${ }^{2}$ Division of Biochemical Pharmacology, Department of Basic Medical Research, Graduate School of Medicine, Ehime University, \\ Shitsukawa, Toon-City, Ehime 791-0295, Japan
}

(Received 26 January 2009 - Revised 23 June 2009 - Accepted 27 July 2009 - First published online 12 October 2009)

We investigated the effects of a high-cholesterol (HC) diet administered long term (25 or 55 weeks) on metabolic disorders including hepatic damage in mice. The mice were fed the HC diet (15\% milk fat, $1.5 \%$ cholesterol and $0.1 \%$ cholic acid, w/w) for 25 or 55 weeks. Body and adipose tissue weights were similar to those of mice fed a control diet. Consumption of the HC diet long term resulted in hypercholesterolaemia, hepatic steatosis and gallstones. In addition, focal nodular hyperplasia (FNH) and mild fibrosis of the liver developed in all mice fed the HC diet for 55 weeks. Plasma levels of monocyte chemoattractant protein (MCP)-1 were elevated, and the level of hepatic platelet-derived growth factor (PDGF)-B protein was increased in mice fed the HC diet compared with those fed the control diet. Thus, it seems likely that the liver fibrosis and FNH caused by the long-term consumption of a HC diet may be partly due to an elevation of plasma MCP-1 and hepatic PDGF expression.

High-cholesterol diet: Hepatic focal nodular hyperplasia: Hepatic fibrosis: Platelet-derived growth factor

Metabolic disorders (obesity, hypertriacylglycerolaemia, hypercholesterolaemia, hyperinsulinaemia, insulin resistance and hypertension) are a risk factor for CHD and atherosclerosis. They are also likely to result in fatty liver and cholesterol gallstones $^{(1-3)}$. Hypercholesterolaemia is considered a major risk factor for atherosclerosis; and was found to cause hepatic damage $^{(4,5)}$. Although excess of dietary cholesterol reportedly contributes to inflammatory diseases such as atherosclero$\operatorname{sis}^{(6,7)}$, proof that liver fibrosis and focal nodular hyperplasia $(\mathrm{FNH})$ are caused by the long-term consumption of a highcholesterol (HC) diet has not yet been obtained.

Day \& James ${ }^{(8)}$ proposed the 'two-hits' theory for the progression of steatohepatitis: the first hit being hepatic steatosis and the second being steatohepatitis with inflammation. A HC diet causes vascular inflammation including atherosclerosis, but the pathogenesis of non-alcoholic steatohepatitis and FNH caused by the chronic consumption of a HC diet is not clear. Therefore, here we examined the effects of a HC diet taken long term on the progression of hepatic damage.

\section{Materials and methods}

\section{Materials}

Maize starch, casein, the mineral mixture American Institute of Nutrition (AIN)-76 and the vitamin mixture AIN-76 were purchased from Oriental Yeast Co., Ltd (Tokyo, Japan). The Triglyceride E-Test, Triglyceride-Test, Total Cholesterol E-Test and NEFA C-Test were obtained from Wako Pure Chemical (Osaka, Japan). The Adiponectin and Leptin ELISA Kits were purchased from Otsuka Pharmaceutical Co., Ltd (Tokyo, Japan) and Morinaga Institute of Biological Science Inc. (Yokohama, Japan), respectively. The monocyte chemoattractant protein-1 (MCP-1), TNF- $\alpha$, transforming growth factor (TGF)- $\beta 1$ and IL- $1 \beta$ ELISA Kits were from R\&D Systems, Inc. (Minneapolis, MN, USA). 3-Hydroxy-3methyl $\left[3-{ }^{14} \mathrm{C}\right]$ glutaryl-coenzyme $\mathrm{A}$ and $\left[1-{ }^{14} \mathrm{C}\right]$ acetylcoenzyme A were obtained from Amersham Biosciences UK Limited (Little Chalfont, Bucks, UK). Other chemicals were of reagent grade.

\section{Animals and diet}

Male C57BL/6J mice, aged 4 weeks, were obtained from Japan SLC (Shizuoka, Japan). They were housed in a room with a $12 \mathrm{~h}$ light-dark cycle and controlled temperature and humidity. They were fed a standard laboratory diet $(8 \mathrm{~g}$ water, $51.3 \mathrm{~g}$ crude carbohydrate, $24.6 \mathrm{~g}$ crude protein, $5.6 \mathrm{~g}$ crude lipid, $3.1 \mathrm{~g}$ crude fibre, $6.4 \mathrm{~g}$ mineral mixture and $1 \mathrm{~g}$ vitamin mixture per $100 \mathrm{~g}$ diet; Oriental Yeast Co., Ltd, Osaka, Japan) for 1 week to adapt to the lighting conditions. After this period of adaptation, they were allowed free access to water and the

Abbreviations: FAS, fatty acid synthase; FNH, focal nodular hyperplasia; HC, high-cholesterol; HMG, 3-hydroxymethylglutaryl; MCP-1, monocyte chemoattractant protein-1; PDGF, platelet-derived growth factor; TGF- $\beta 1$, transforming growth factor- $\beta 1$

* Corresponding author: Dr Yoshiyuki Kimura, fax +89 89960 5239, email yokim@m.ehime-u.ac.jp 
Table 1. Composition of experimental diets $(\mathrm{g} / \mathrm{kg})$

\begin{tabular}{lcc}
\hline & $\begin{array}{c}\text { Low-fat-low-sucrose } \\
\text { (control) diet }\end{array}$ & $\begin{array}{c}\text { High-cholesterol } \\
\text { diet }\end{array}$ \\
\hline Milk fat & 30.0 & 150.0 \\
Maize starch & 415.0 & 355.0 \\
Sucrose & 50.0 & 100.0 \\
Casein & $200 \cdot 0$ & 200.0 \\
Cellulose & 30.0 & 30.0 \\
Mineral mix & 35.0 & 35.0 \\
Choline chloride & 4.0 & 4.0 \\
Vitamin mix & 10.0 & 10.0 \\
Cholesterol & 0.0 & 15.0 \\
Cholic acid & 0.0 & 1.0 \\
Water & 226.0 & 100.0 \\
Energy (MJ/kg) & 12.3 & 16.5 \\
\hline
\end{tabular}

* Mineral and vitamin mixtures (American Institute of Nutrition (AIN)-76) were purchased from Oriental Yeast Co., Ltd (Tokyo, Japan)

experimental diets listed in Table 1 for 25 or 55 weeks. A lowfat and low-sucrose diet was used as the control diet in the present study. Animal experiments were performed according to the ethical guidelines of the Animal Experimentation, Ehime University and Japanese Pharmacological Society, and guide for the care and use of laboratory animals of the National Institutes of Health. The animal experiments were approved by the Ethics Committee on Animal Experimentation, Ehime University (approval no. YA-8-1).

\section{Plasma analysis}

At 25 or 55 weeks, after fasting overnight, blood was obtained from each mouse by venous puncture under anaesthesia with Nembutal $^{\circledR} \quad$ (Dainippon Pharmaceutical Co. Ltd, Osaka, Japan), and then the mice were killed with an overdose of Nembutal ${ }^{\circledR}$. Blood samples were chilled in test-tubes containing heparin and centrifuged to give plasma. The plasma was frozen at $-20^{\circ} \mathrm{C}$ before analysis. TAG and total cholesterol concentrations in the plasma were determined using the TAG E-Test and Total Cholesterol E-Test kits. The concentrations of MCP-1, TNF- $\alpha$, leptin and adiponectin in the plasma were measured using the respective ELISA kits.

\section{Oral glucose tolerance test}

The oral glucose tolerance test was carried out at weeks 25 and 55. After at least $4 \mathrm{~h}$ of food deprivation, glucose ( $100 \mathrm{mg} / \mathrm{mouse})$ was administered orally to the mice. Blood samples were taken from the tail $0,10,20,30$ and $60 \mathrm{~min}$ after glucose administration. The blood glucose concentrations were measured using GLUCOCARD ${ }^{\circledR}$ (GT-1640; Arkray Co., Kyoto, Japan).

\section{Liver lipid contents and cytokine levels, and cholesterol content in gallstones}

TAG and total cholesterol levels in liver were measured by the methods of Fletcher ${ }^{(9)}$ and Zak et al. ${ }^{(10)}$. A piece of the liver was homogenised in the protein extraction reagent $\left(\mathrm{T}-\mathrm{PER}^{\circledR}\right.$; Pierce Biotechnology, Inc., Rockford, IL, USA), and centrifuged. The TGF- $\beta 1$ and IL-1 $\beta$ levels in the supernatant fraction were measured using the respective ELISA kits. Gallstones were collected from gallbladder and extracted with an acetone-ethanol $(1: 1, \mathrm{v} / \mathrm{v})$ mixture, and then cholesterol contents in gallstones were measured by the methods of Zak et al. ${ }^{(10)}$.

\section{Histological examination}

Liver was fixed in $10 \%(\mathrm{v} / \mathrm{v})$ buffered formalin, embedded in paraffin, and sectioned. The liver segments were stained with haematoxylin and eosin and with the Azan stain. The main artery was embedded in Tissue-Tek ${ }^{\circledR}$ (OTC compound; Sakura Finetech Co. Ltd, Tokyo, Japan) and frozen, and frozen sections were examined for macrophages at the vessel wall by an immunoperoxidase technique using an anti-macrophage antibody (clone MAC 387; Lab Vision Co., Fremont, CA, USA).

\section{Enzyme activity}

3-Hydroxymethylglutaryl-CoA reductase. The liver microsomal fraction was separated by the method of Daniele et al. ${ }^{(11)}$. Briefly, the liver was cut and homogenised immediately on ice in $10 \mathrm{~mm}$-HEPES buffer ( $\mathrm{pH} 7 \cdot 2)$ containing $0 \cdot 25 \mathrm{M}$-sucrose and protease inhibitor, using a Teflon glass homogeniser. The homogenate was centrifuged at $9000 \mathrm{~g}$ for $20 \mathrm{~min}$ at $4^{\circ} \mathrm{C}$. Then the supernatant fraction was further centrifuged at $105000 \mathrm{~g}$ for $60 \mathrm{~min}$ at $4^{\circ} \mathrm{C}$. The microsomal pellet was suspended in 0.1 M-phosphate buffer ( $\mathrm{pH} 7 \cdot 4$ ), and added to a reaction mixture containing $0 \cdot 128 \mathrm{~mm}$-3-hydroxymethylglutaryl (HMG)-CoA ([ $\left.\left.{ }^{14} \mathrm{C}\right] \mathrm{HMG}-\mathrm{CoA}, 144 \mathrm{MBq} / \mathrm{mmol}\right)$, $1 \mathrm{mM}-\mathrm{NADPH}, 10 \mathrm{~mm}$-dithiothreitol and $10 \mathrm{mM}$-EDTA in $0 \cdot 12 \mathrm{M}$-phosphate buffer ( $\mathrm{pH} 7 \cdot 4$ ). The mixture was incubated at $37^{\circ} \mathrm{C}$ for $15 \mathrm{~min}$, added to $2 \mathrm{M}-\mathrm{HCl}$, and further incubated for $15 \mathrm{~min}$ to allow lactonisation of the mevalonic acid produced. This reaction mixture was spotted on a silica gel 60 F254 TLC plate (Merck, Germany), and developed with benzene-acetone $(1: 1, \mathrm{v} / \mathrm{v})^{(12)}$. The radioactive spot corresponding to mevalonate lactone was measured using a BAS 1000 image analyser (Fuji Film, Tokyo, Japan). The HMG-CoA reductase activity was expressed as nmol mevalonic acid per mg protein.

Fatty acid synthase. Liver was homogenised on ice in 10 mM-HEPES buffer ( $\mathrm{pH} 7 \cdot 2$ ) containing $0.25 \mathrm{M}$-sucrose and protease inhibitor, and centrifuged at $12000 \mathrm{~g}$ for $10 \mathrm{~min}$ at $4^{\circ} \mathrm{C}$. The activity was determined by measuring the incorporation of $\left[{ }^{14} \mathrm{C}\right]$ acetyl-CoA into fatty acids ${ }^{(13)}$. The supernatant fraction was added to a reaction mixture containing $0.062 \mathrm{mM}-\left[{ }^{14} \mathrm{C}\right]$ acetyl-CoA (148 MBq/mmol), $0.195 \mathrm{mM}-$ malonyl-CoA, $\quad 0.5 \mathrm{~mm}-\mathrm{NADPH}, \quad 0.45 \mathrm{~mm}$-dithiothreitol, $1 \mathrm{mM}$-EDTA and $0.93 \%$ bovine serum albumin in $100 \mathrm{~mm}-$ HEPES buffer ( $\mathrm{pH} 6.8$ ), and then incubated at $37^{\circ} \mathrm{C}$ for $10 \mathrm{~min}$. The reaction was stopped by the addition of chloroform-methanol $(2: 1, v / v)$, and mixed with a vortex. After centrifugation, the supernatant fraction was removed by aspiration, and the residue was washed with water in acidic conditions twice. The residual radioactivity was quantified with a liquid scintillation counter. The fatty acid synthase (FAS) activity was expressed per mg protein. 
Table 2. Body and adipose tissue weight, and plasma levels of lipids, monocyte chemoattractant protein-1 (MCP-1) and adiponectin in mice fed a control diet or high-cholesterol (HC) diet for 25 or 55 weeks

(Mean values with their standard errors for six or seven mice per group)

\begin{tabular}{|c|c|c|c|c|c|c|c|c|}
\hline & \multicolumn{4}{|c|}{ Week 25} & \multicolumn{4}{|c|}{ Week 55} \\
\hline & \multicolumn{2}{|c|}{ Control diet $(n 7)$} & \multicolumn{2}{|c|}{$\mathrm{HC}$ diet $(n 6)$} & \multicolumn{2}{|c|}{ Control diet $(n 6)$} & \multicolumn{2}{|c|}{$\mathrm{HC}$ diet $(n 6)$} \\
\hline & Mean & SEM & Mean & SEM & Mean & SEM & Mean & SEM \\
\hline Body weight (g) & $34 \cdot 0$ & 0.8 & $33 \cdot 1$ & 1.0 & $40 \cdot 7$ & 1.5 & 43.7 & 1.4 \\
\hline Epididymal adipose tissue weight $(\mathrm{g})$ & 0.43 & 0.06 & 0.50 & 0.14 & 1.42 & 0.31 & 1.85 & 0.28 \\
\hline TAG $(\mathrm{mmol} / \mathrm{l})$ & 0.51 & 0.04 & 0.46 & 0.05 & 0.39 & 0.05 & $0.72^{*}$ & 0.08 \\
\hline Total cholesterol $(\mathrm{mmol} / \mathrm{l})$ & 1.95 & 0.12 & $2 \cdot 54^{\star}$ & 0.11 & $3 \cdot 20$ & 0.55 & 3.51 & 0.35 \\
\hline $\mathrm{NEFA}(\mathrm{mmol} / \mathrm{l})$ & 0.29 & 0.03 & 0.36 & 0.03 & 0.29 & 0.03 & $0.66^{*}$ & 0.08 \\
\hline Glucose (mg/100 ml) & $137 \cdot 3$ & $5 \cdot 9$ & $122 \cdot 7$ & $6 \cdot 7$ & $109 \cdot 3$ & $12 \cdot 3$ & $130 \cdot 6$ & 5.8 \\
\hline MCP-1 $(\mathrm{pg} / \mathrm{ml})$ & $67 \cdot 2$ & 6.9 & $65 \cdot 6$ & $11 \cdot 0$ & $105 \cdot 2$ & $17 \cdot 4$ & $211 \cdot 7^{*}$ & $40 \cdot 6$ \\
\hline Leptin (ng/ml) & $6 \cdot 9$ & $2 \cdot 2$ & $12 \cdot 2$ & 5.4 & $50 \cdot 1$ & 24.4 & $40 \cdot 0$ & $9 \cdot 3$ \\
\hline Adiponectin $(\mu \mathrm{g} / \mathrm{ml})$ & $17 \cdot 9$ & $2 \cdot 9$ & $19 \cdot 8$ & $2 \cdot 9$ & $15 \cdot 8$ & 1.8 & $13 \cdot 2$ & 1.7 \\
\hline
\end{tabular}

${ }^{*}$ Mean value was significantly different from that of the mice fed the control diet $(P<0.05)$.

\section{Immunoblotting}

Liver was homogenised in a solubilising buffer (50 mM-HEPES buffer ( $\mathrm{pH} 7.4)$ containing $5 \mathrm{~mm}-\mathrm{EDTA}, 150 \mathrm{~mm}-\mathrm{NaCl}, 1 \%$ TritonX-100, $0.5 \%$ sodium deoxycholate and protease inhibitor) and then centrifuged at $12000 \mathrm{~g}$ for $15 \mathrm{~min}$ at $4^{\circ} \mathrm{C}$. The amount of protein in the supernatant fraction was measured using a protein assay reagent (Bio-Rad, Hercules, CA, USA). After being denatured at $99^{\circ} \mathrm{C}$, the protein was resolved by $12 \%$ SDS-PAGE. The gel was transferred to a polyvinylidene fluoride membrane, and the membrane was blocked with $5 \%$ skimmed milk. The membrane was incubated with an anti-platelet-derived growth factor (PDGF) antibody (Novus Biological, Inc., Littleton, CO, USA; 1:1000). Immunoreactivity was visualised with alkaline phosphatase-conjugated goat anti-rabbit IgG (ICN Pharmaceuticals, Cleveland, $\mathrm{OH}$, USA) and BCIP/NBT solution (Sigma, St Louis, MO, USA). The blots were measured using the ImageJ program (National Institutes of Health, Bethesda, MD, USA). The ratio is the intensity of the PDGF blots normalised to the blot of glyceraldehyde-3-phosphate dehydrogenase.

\section{Statistical analysis}

All values are expressed as the mean values with their standard errors. The Dunnett test was used to compare the two groups. Differences were considered significant at $P<0.05$.

\section{Results}

Plasma lipid, glucose, monocyte chemoattractant protein-1, $T N F-\alpha$, leptin and adiponectin levels in mice fed the highcholesterol diet

The body weights and epididymal adipose tissue weights of mice fed the control diet and $\mathrm{HC}$ diet were similar at weeks 25 and 55 (Table 2). The mean food consumption/mouse per $\mathrm{d}$ for 55 weeks was not different between mice fed the control diet and the HC diet: 54.5 (SEM 0.53) kJ/mouse per d (control diet) and 55.2 (SEM 0.99) kJ/mouse per d (HC diet). The fasting plasma glucose levels were not significantly different between the groups at weeks 25 and 55. To confirm glucose tolerance, oral glucose tolerance tests were performed at weeks 25 and 55. There were no differences in plasma glucose levels after the oral administration of glucose between the two groups (data not shown). At week 25, plasma levels of total cholesterol were significantly higher in the mice fed the $\mathrm{HC}$ diet. Levels of plasma, NEFA, MCP-1, leptin and adiponectin were not significantly different between the groups at week 25, but plasma TAG and NEFA levels were significantly elevated in the mice fed the HC diet at week 55. MCP-1 levels of mice fed the HC diet long term (55 weeks) were markedly increased compared with those of mice fed the control diet. On the other hand, plasma leptin and adiponectin levels did not differ between the two groups at week 55 .

Table 3. Liver weight, hepatic lipid contents and cholesterol gallstones in mice fed a control diet or high-cholesterol (HC) diet for 25 or 55 weeks

(Mean values with their standard errors for six or seven mice per group)

\begin{tabular}{|c|c|c|c|c|c|c|c|c|}
\hline & \multicolumn{4}{|c|}{ Week 25} & \multicolumn{4}{|c|}{ Week 55} \\
\hline & \multicolumn{2}{|c|}{ Control diet $(n 7)$} & \multicolumn{2}{|c|}{$\mathrm{HC}$ diet $(n 6)$} & \multicolumn{2}{|c|}{ Control diet $(n 6)$} & \multicolumn{2}{|c|}{$\mathrm{HC}$ diet $(n 6)$} \\
\hline & Mean & SEM & Mean & SEM & Mean & SEM & Mean & SEM \\
\hline Liver weight (g) & 1.69 & 0.06 & $2 \cdot 25^{\star}$ & 0.10 & 3.43 & 0.57 & 4.82 & 0.68 \\
\hline TAG $(\mu \mathrm{mol} / \mathrm{g})$ & 2.57 & $0 \cdot 15$ & $4.44^{\star}$ & 0.69 & 19.08 & $6 \cdot 11$ & $6 \cdot 37^{\star}$ & $1 \cdot 19$ \\
\hline Total cholesterol $(\mu \mathrm{mol} / \mathrm{g})$ & 1.20 & 0.03 & $10 \cdot 99^{*}$ & 0.44 & $4 \cdot 15$ & 0.90 & $10 \cdot 45^{*}$ & 1.61 \\
\hline Cholesterol in gallstones $(\mathrm{mg})$ & None & - & $9 \cdot 02$ & 1.44 & None & - & 8.55 & $2 \cdot 61$ \\
\hline Gallstone incidence $(n)$ & \multicolumn{2}{|c|}{0} & \multicolumn{2}{|c|}{6} & \multicolumn{2}{|c|}{0} & \multicolumn{2}{|c|}{6} \\
\hline
\end{tabular}

${ }^{*}$ Mean value was significantly different from that of the mice fed the control diet $(P<0.05)$. 
Plasma TNF- $\alpha$ was not detected in the control diet- and HC diet-treated mice (data not shown).

\section{Hepatic lipid accumulation and gallstone formation induced by the high-cholesterol diet}

At week 25, liver hypertrophy was observed, and liver weight was significantly increased in the mice fed the $\mathrm{HC}$ diet (Table 3). The hepatic accumulation of lipids was also markedly enhanced in these mice. In addition, consumption of the $\mathrm{HC}$ diet resulted in cholesterol gallstones. Hepatic hypertrophy induced by the consumption of cholesterol may have contributed to the hepatic lipid accumulation. At week 55, hepatic TAG levels were greater in mice fed the control diet than in mice fed the $\mathrm{HC}$ diet (Table 3).

\section{Hepatic lipogenesis}

FAS activity in the liver was greater in mice fed the control diet than in those on the $\mathrm{HC}$ diet at weeks 25 and 55 (Fig. 1). The activity of HMG-CoA reductase, a key enzyme of cholesterol synthesis, was lower in the mice fed the HC diet at weeks 25 and 55 (Fig. 1).

\section{Liver focal nodular hyperplasia and fibrosis, and macrophage} accumulation into the vessel walls

Hepatic hyperplastic pseudotumours were found in the mice fed the HC diet for 55 weeks (Fig. 2(a)). Based on the histological analysis, the $\mathrm{HC}$ diet caused $\mathrm{FNH}$, and lipid accumulation and fibrosis were observed around the hyperplastic region (Fig. 2(b) and (c)). The chronic intake of the $\mathrm{HC}$ diet for 55 weeks caused the accumulation of macrophages into the vessel walls (Fig. 2(d)).

Effects of the high-cholesterol diet on hepatic IL-1 $\beta$,

transforming growth factor- $\beta 1$ and platelet-derived growth factor protein levels

As shown in Fig. 3(a) and (b), TGF- $\beta 1$ and IL-1 $\beta$ levels did not differ between the two groups at weeks 25 and 55. However, PDGF-B protein levels were significantly increased in the mice fed the HC at weeks 25 and 55 (Fig. 3(c)).

\section{Discussion}

The body and adipose tissue weights, and the food consumption of the mice fed the control diet were similar to those of mice fed the HC diet (Table 2). Chronic consumption of the $\mathrm{HC}$ diet resulted in the hepatic accumulation of cholesterol and crystallisation in the gallbladder (Table 3). Therefore, these findings suggest that the influence on liver function may be due to dietary cholesterol in the diet composition rather than the difference of energy intake of the two diets. Blood and liver total cholesterol levels were increased by feeding the HC diet, and the increases of blood and hepatic total cholesterol might have been due to dietary cholesterol rather than endogenous cholesterol synthesis in the liver, because these mice showed a reduction of HMG-CoA reductase (Fig. 1(a)). In fact, the HMG-CoA reductase in the control diet-treated mice was significantly greater than that in the $\mathrm{HC}$ diet-treated mice. HMG-CoA reductase was not significantly different between feeding for 25 and 55 weeks in the control diet-fed mice. On the other hand, HMG-CoA reductase in the $\mathrm{HC}$ diet-fed mice for 25 weeks tended to be greater than that in the $\mathrm{HC}$ diet-fed mice for 55 weeks. Therefore, it seems likely that the longer feeding $\mathrm{HC}$ diet results in the reduction of endogenous cholesterol synthesis by the supply of dietary cholesterol; consequently the differences for increasing rate in plasma total cholesterol may have occurred during week 25 to 55 in the control and the $\mathrm{HC}$
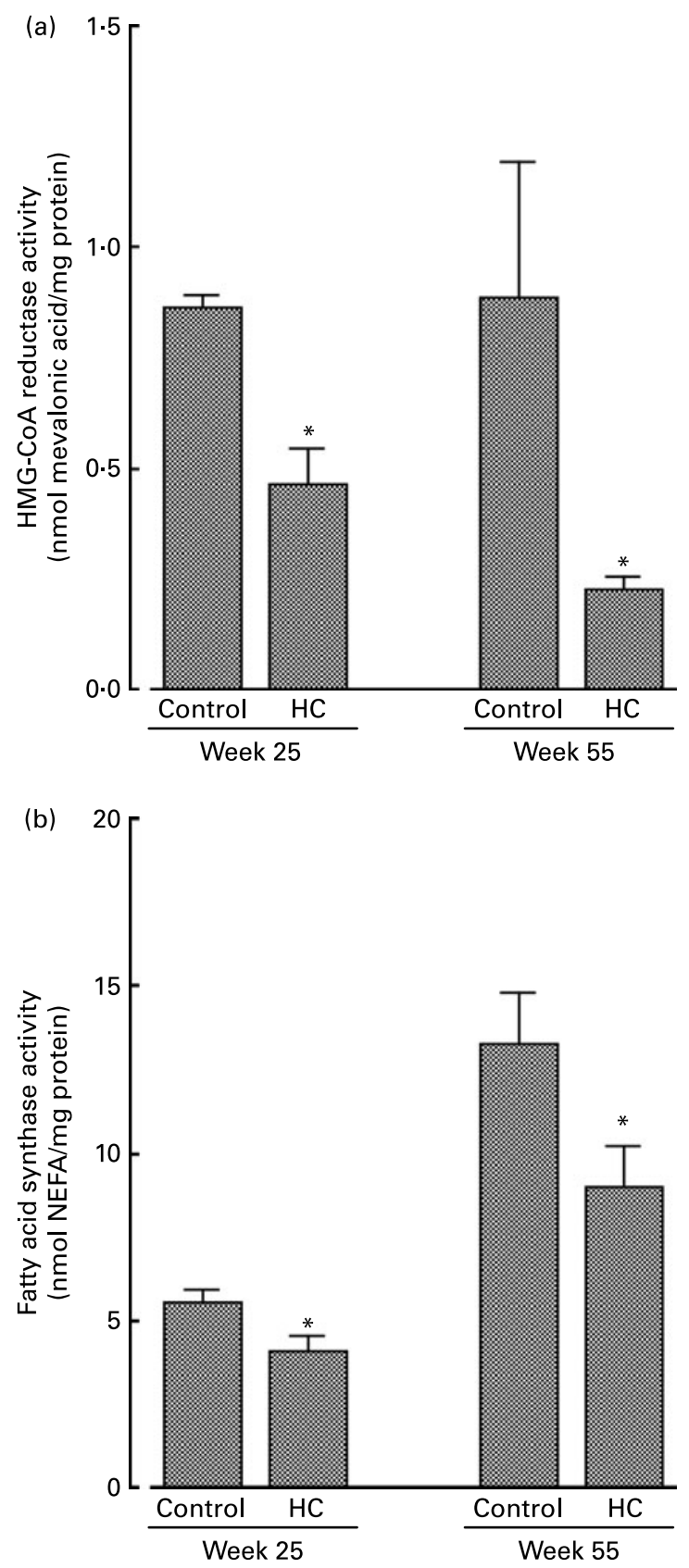

Fig. 1. Fatty acid synthase activity (a) and 3-hydroxymethylglutaryl-CoA (HMG-CoA) reductase activity (b) in the liver of mice fed a high-cholestero (HC) diet or a control diet. Values are means $(n 6-7)$, with standard errors represented by vertical bars. * Mean value was significantly different from that of the mice fed the control diet $(P<0.05)$. 
diet-fed mice. Thus, cholesterol synthesis is controlled by the absorption of dietary cholesterol. On the other hand, hepatic FAS activity was increased in mice fed the control diet, and hepatic TAG accumulation was observed at week 55. It has been reported that a high-carbohydrate (starch) diet is implicated in stimulating FAS activity and lipogenesis ${ }^{(14,15)}$. In fact, the control diet used in the present study is a high-carbohydrate diet including $46.5 \%(\mathrm{w} / \mathrm{w})$ carbohydrate. We found that hepatic FAS activity in the control diet-fed mice was significantly $(P<0.05)$ greater than that in the HC diet-fed mice, and hepatic TAG accumulation was significantly $(P<0.05)$ higher in mice fed the control diet than in mice fed the HC diet at week 55. These findings suggested that the higher levels of FAS activity in mice fed the control diet stimulated the hepatic TAG accumulation.
An excess of dietary cholesterol contributes to inflammatory diseases such as atherosclerosis ${ }^{(6)}$. In the present study, chronic consumption of the $\mathrm{HC}$ diet caused hepatic fibrosis and $\mathrm{FNH}$ (Fig. 2(b)) and macrophages to accumulate in vessel walls (Fig. 2(d)). MCP-1 is an angiogenic factor ${ }^{(16,17)}$ involved in the progression of atherosclerosis associated with inflammation in vascular disease ${ }^{(18-20)}$. Furthermore, we reported that a highfat diet caused obese mice to develop insulin resistance associated with higher plasma MCP-1 levels ${ }^{(21)}$. The progression of obesity is associated with the accumulation of macrophages and overexpression of MCP-1 in adipose tissue; which induces inflammation and insulin resistance ${ }^{(22,23)}$. Kanda et al. ${ }^{(24)}$ reported that the overexpressing MCP-1 gene in adipose tissue was caused by a high-fat diet (33 weeks) in C57BL/6J mice, and that MCP-1 contributes to macrophage infiltration into (a)

Control
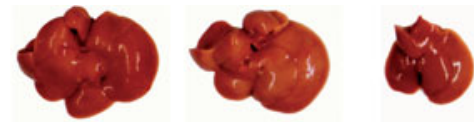

$\mathrm{HC}$
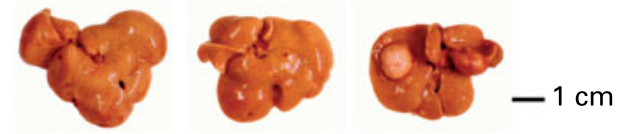

(b)

Control

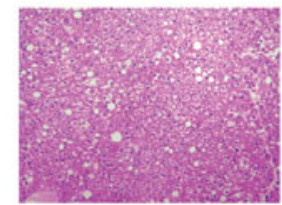

(c)
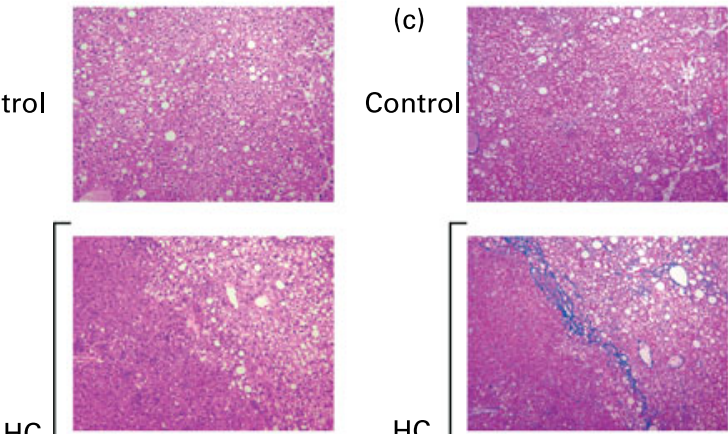

$\mathrm{HC}$

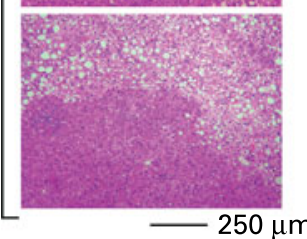

\lceil

$\mathrm{HC}$
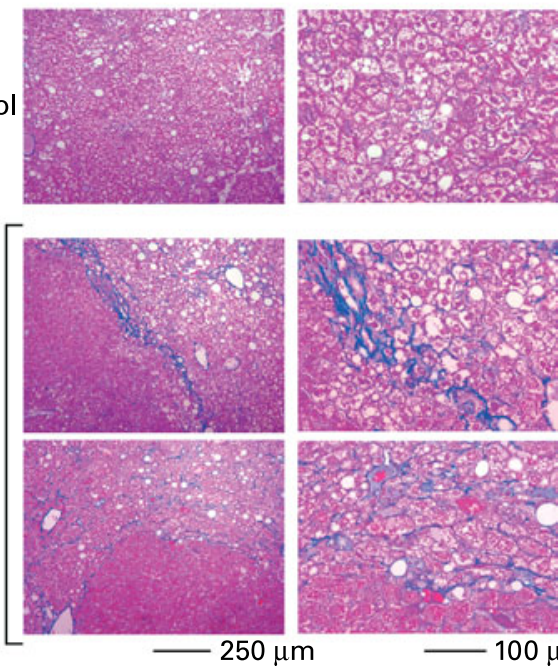

(d)

Control
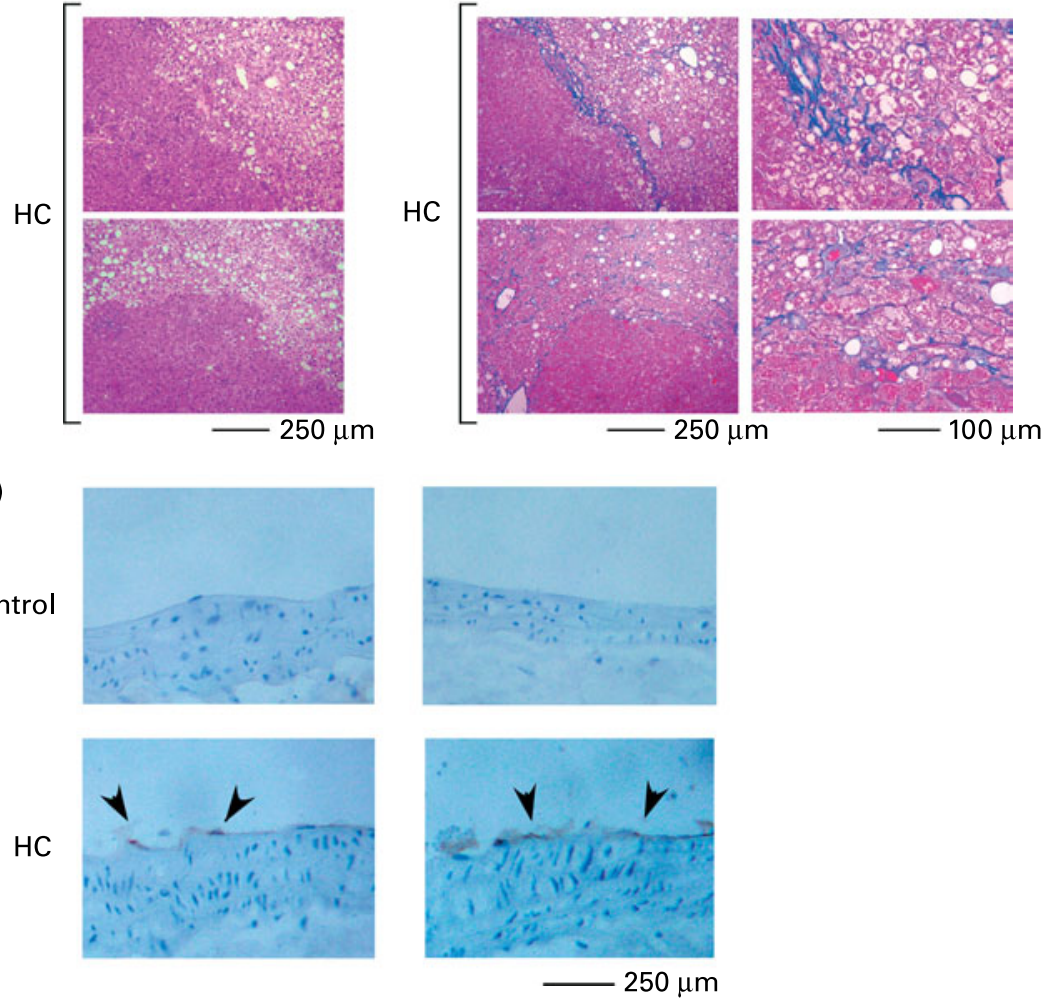

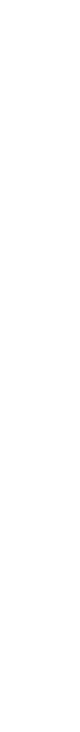

Fig. 2. Livers (a), liver sections (b, c), and vessel wall sections (d) of mice fed a control diet or high-cholesterol (HC) diet for 55 weeks. In mice fed the HC diet, liver focal nodular hyperplasia (a, b: haematoxylin and eosin stain) and mild fibrosis (c: azan stain) were detected, and macrophage accumulation ( $\downarrow$ ) into the vessel walls was detected by immunohistochemistry using an anti-macrophage antibody (d). 
adipose tissue, insulin resistance, and hepatic steatosis with the accumulation of TAG in obesity. Thus, it seems likely that an increase in blood MCP-1 is closely associated with the progression of obesity and glucose intolerance ${ }^{(21,22)}$. Furthermore, it has been reported that chronic infection such as periodontal diseases induces hypertriacylglycerolaemia and increases serum MCP-1 levels in a manner that increases the risk of atherosclerotic CVD ${ }^{(25)}$. However, we found that elevation of the plasma MCP-1 level was independent of adiposity in mice fed a high-sucrose diet for a long period ${ }^{(21)}$. In the present study, consumption long-term (for 55 weeks) of the HC diet markedly increased the plasma MCP-1 level without affecting obesity and glucose intolerance, compared with that in mice fed the control diet (Table 2). It has been reported that MCP-1 $1^{(26-29)}$ and leptin $^{(30-32)}$ play a significant role in the development of progressive liver fibrosis. Conversely, adiponectin inhibits the proliferation of hepatic stellate cells and hepatic fibrosis through the activation of adenosine monophosphate kinase-activated protein kinase ${ }^{(33)}$. Thus, MCP-1, leptin and adiponectin were closely associated with the development of liver fibrosis. In the present study, we found that plasma leptin and adiponectin levels did not differ between the control diet-fed group and the $\mathrm{HC}$ diet-fed group at week 55, but the plasma MCP-1 level was greater in the mice fed the $\mathrm{HC}$ diet. Therefore, it seems likely that the fibrosis and macrophage accumulation into the vessel walls caused by long-term consumption of a $\mathrm{HC}$ diet is due to an elevation of the plasma MCP-1 level brought about by chronic inflammation, and that the elevated MCP-1 may be due to increases in plasma TAG, and the elevated TAG may be a causal factor for the liver fibrosis and FNH. Isoda et al. ${ }^{(34)}$ reported that IL-1 $\mathrm{Ra}^{-/-}$mice developed severe non-alcoholic fatty liver disease and portal fibrosis following 20 weeks on an atherogenic diet when compared with wild-type mice. Furthermore, they found that mRNA levels of IL-1 $\beta$ and TGF- $\beta$ were significantly elevated in the livers of $\mathrm{IL}-1 \mathrm{Ra}^{-1-}$ mice ${ }^{(34)}$. Liver fibrosis is the excessive accumulation of extracellular matrix proteins including collagen that occurs in most types of chronic liver diseases. There is substantial evidence that hepatic stellate cells are the main producers of collagen and extracellular matrix during liver fibrosis. PDGF and TGF- $\beta$ are activated in the hepatic stellate cells, and it is well documented that the two cytokines cause the development of liver fibrosis ${ }^{(35-42)}$. Studies have identified PDGF as the main mediator for proliferation and
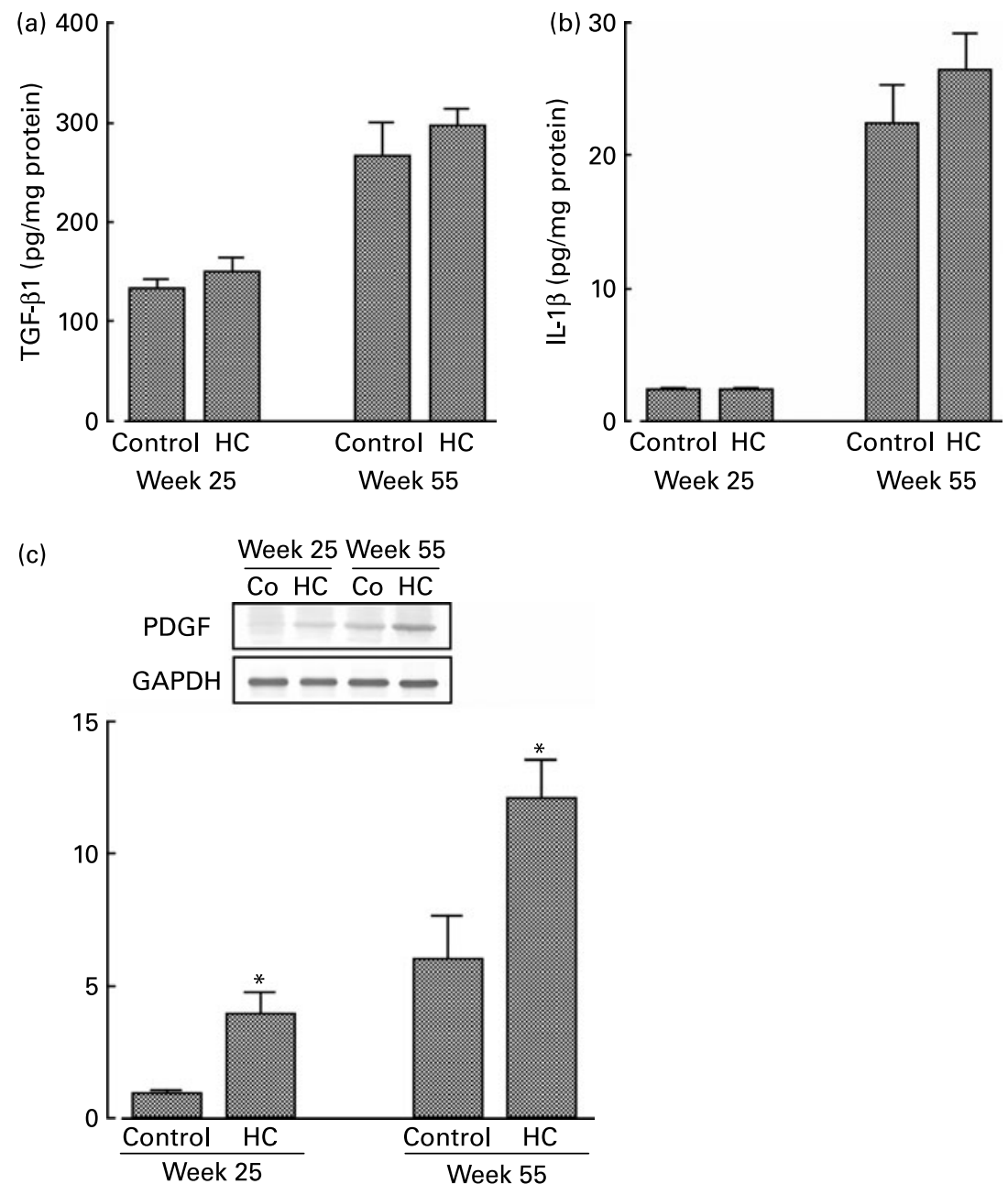

Fig. 3. Transforming growth factor (TGF)- $\beta 1$ (a), IL-1 $\beta$ (b) and platelet-derived growth factor (PDGF)-B (c) levels in the liver of mice fed a high-cholesterol (HC) diet or a control (Co) diet. GAPDH, glyceraldehyde-3-phosphate dehydrogenase. Values are means $(n 6-7)$, with standard errors represented by vertical bars. ${ }^{*}$ Mean value was significantly different from that of the mice fed the control diet $(P<0.05)$. 
TGF- $\beta$ as the most important cytokine stimulating fibrogenesis in hepatic stellate cells ${ }^{(35-42)}$. As expected, hepatic IL-1 $\beta$ and TGF- $\beta 1$ levels were greater in mice fed the control diet or HC diet than in those given a laboratory chow diet (Oriental Co., Osaka, Japan) (data not shown). Feeding on the HC diet longterm (55 weeks) caused hepatic FNH and fibrosis, but the control diet caused neither hepatic FNH nor fibrosis. Hepatic IL-1 $\beta$ and TGF- $\beta 1$ levels did not differ between the control diet-fed group and the HC diet-fed group. Therefore, the hepatic FNH and fibrosis caused by chronic consumption of the HC diet could not be explained by the increase in IL- $1 \beta$ and TGF- $\beta 1$ levels in the liver. PDGF-B had been the most potent mitogen in cultures of activated hepatic stellate cells ${ }^{(43)}$. Czochra et al. ${ }^{(44)}$ reported that hepatic PDGF-B overexpression causes liver fibrosis without significantly up-regulating TGF- $\beta 1$ expression. Long-term consumption of the $\mathrm{HC}$ diet caused an increase in the hepatic PDGF-B protein level (Fig. 3). In addition, we found $\mathrm{FNH}$ of the liver together with liver fibrosis in the HC diet-fed mice (Fig. 2). Although the pathogenesis of $\mathrm{FNH}$ in the liver remains unclear, it has been reported that TGF- $\beta 1$ protein was strongly expressed in FNH of human liver ${ }^{(45)}$, and that liver FNH was closely associated with vascular malformation and liver fibrosis through inflammation ${ }^{(46-49)}$.

Chronic consumption of a HC diet causes non-obese fatty liver, FNH and fibrosis with an elevation of the plasma MCP-1 level and an increase in hepatic PDGF expression without affecting plasma leptin and adiponectin levels, or hepatic IL-1 $\beta$ and TGF- $\beta 1$ levels. It is suggested that the incidence and/or development of liver FNH and fibrosis caused by the chronic intake of a $\mathrm{HC}$ diet may be partly due to the increases in blood MCP-1 and TAG levels and/or hepatic PDGF-B expression in the absence of increase in leptin in the present study. Further studies are needed to clarify the processes of hepatic inflammation and damage caused by a diet rich in cholesterol.

\section{Acknowledgements}

Animal experiments were performed according to the ethical guidelines of the Animal Experimentation, Ehime University and Japanese Pharmacological Society, and guide for the care and use of laboratory animals of the National Institutes of Health. The animal experiments were approved by the Ethics Committee on Animal Experimentation, Ehime University (approval number: YA-8-1).

M. S. designed the experiment, performed all the experimental analysis and wrote the manuscript. M. S. contributed to the discussion of the manuscript. Y. K. conducted all the experimental work, wrote the manuscript and discussed it with the whole group of authors. All authors read and approved the final manuscript.

There were no sources of funding.

The authors declare that there are no conflicts of interest in respect of the present study.

\section{References}

1. Reaven GM (1988) Role of insulin resistance on human disease. Diabetes 37, 1595-1607.
2. Plutzky J (2000) Emerging concepts in metabolic abnormalities associated with coronary artery disease. Curr Opin Cardiol 15, 416-421.

3. Portincasa P, Moschetta A \& Palasciano G (2006) Cholesterol gallstone disease. Lancet 368, 230-239.

4. Buyssens N, Kockx MM, Herman AG, et al. (1996) Centrolobular liver fibrosis in the hypercholesterolemic rabbit. Hepatology 24, 939-946.

5. Jeong WI, Jeong DH, Do SH, et al. (2005) Mild hepatic fibrosis in cholesterol and sodium cholate diet-fed rats. J Vet Med Sci 67, 235-242.

6. Kleemann R \& Kooistra T (2005) HMG-CoA reductase inhibitors: effects on chronic subacute inflammation and onset of atherosclerosis induced by dietary cholesterol. Curr Drug Targets Cardiovasc Haematol Disord 5, 441-453.

7. Kleemann R, Verschuren L, Erk MJ, et al. (2007) Atherosclerosis and liver inflammation induced by increased dietary cholesterol intake: a combined transcriptomics and metabolomics analysis. Genomic Biol 8, R200.

8. Day CP \& James OF (1998) Steatohepatitis: a tale of two 'hits'? Gastroenterology 114, 842-845.

9. Fletcher MJ (1968) A colorimetric method for estimating serum triglycerides. Clin Chem Acta 22, 393-397.

10. Zak B, Dickman RC, White EG, et al. (1954) Rapid estimation of free and total cholesterol. Am J Clin Pathol 24, 1307-1315.

11. Daniele F, Rajas F, Payrastre B, et al. (1999) Phosphatidylinositol 3-kinase translocates onto liver endoplasmic reticulum and may account for the inhibition of glucose-6-phosphatase during refeeding. $J$ Biol Chem 274, 3597-3601.

12. Shapiro DJ, Imblum RL \& Rodwell VW (1969) Thin-layer chromatographic assay for HMG-CoA reductase and mevalonic acid. Anal Biochem 31, 383-390.

13. Tijburg LBM, Maquedano A, Bijleveld C, et al. (1988) Effects of ethanol feeding on hepatic lipid synthesis. Arch Biochem Biophys 267, 568-579.

14. Kabir M, Rizkalla SW, Quignard-Boulangé A, et al. (1998) A high glycemic index starch diet affects lipid storage-related enzymes in normal and a lesser extent in diabetic rats. $J$ Nutrition 128, 1878-1883.

15. Jentsch W, Derno M, Klein M, et al. (2000) Research note: is starch utilization for fat deposition in man different from that of animals? Arch Tierernahr 53, 395-398.

16. Bernardini G, Ribatti D, Morbidelli L, et al. (2002) Analysis of the role of chemokines in angiogenesis. J Immunol Methods 273, 83-101.

17. Kim MY, Byeon CW, Hong KH, et al. (2005) Inhibition of the angiogenesis by the MCP-1 (monocyte chemoattractant protein-1) binding peptide. FEBS Lett 579, 1597-1601.

18. Egashira K, Zhao Q, Kataoka C, et al. (2002) Importance of monocyte chemoattractant protein-1 pathway in neointimal hyperplasia after periarterial injury in mice and monkeys. Circ Res 90, 1167-1172.

19. Egashira K (2003) Molecular mechanisms mediating inflammation in vascular disease. Special reference to monocyte chemoattractant protein-1. Hypertension 41, 834-841.

20. Ni W, Kitamoto S, Ishibashi M, et al. (2004) Monocyte chemoattractant protein-1 is an essential inflammatory mediator in angiotensin II-induced progression of established atherosclerosis in hypercholesterolemic mice. Arterioscler Thromb Vasc Biol 24, 534-539.

21. Sumiyoshi M, Sakanaka M \& Kimura Y (2006) Chronic intake of high-fat and high-sucrose diets differentially affects glucose intolerance in mice. $J$ Nutr 136, 582-587.

22. Sartipy P \& Losktoff DJ (2003) Monocyte chemoattractant protein 1 in obesity and insulin resistance. PNAS 100, $7265-7270$. 
23. Weisberg SP, McCann D, Desai M, et al. (2003) Obesity is associated with macrophage accumulation in adipose tissue. J Clin Invest 112, 1796-1808.

24. Kanda H, Tateya S, Tamori Y, et al. (2006) MCP-1 contributes to macrophage infiltration into adipose tissue, insulin resistance, and hepatic steatosis in obesity. J Clin Invest 116, 1494-1505.

25. Uchiumi D, Kobayashi M, Tachikawa T, et al. (2004) Subcutaneous and continuous administration of lipopolysacchride increases serum levels of triglyceride and monocyte chemoattractant protein-1 in rats. J Periodontal Res 39, 120-128.

26. Kanno K, Tazuma S, Nishioka T, et al. (2005) Angiotensin II participates in hepatic inflammation and fibrosis through MCP-1 expression. Dig Dis Sci 50, 942-948.

27. Kobayashi H, Tamatani T, Tamura T, et al. (2006) The role of monocyte chemoattractant protein-1 in biliary artesia. $J$ Pediatr Surg 41, 1967-1972.

28. Gäbele E, Mühlbauer M, Dorn C, et al. (2008) Role of TLR9 in hepatic stellate cells and experimental liver fibrosis. Biochem Biophys Res Commun 376, 271-276.

29. Desai MS, Mariscalco MM, Tawil A, et al. (2008) Atherogenic diet-induced hepatitis is partly dependent on murine TLR4. J Leukoc Biol 83, 1336-1344.

30. Ikejima K, Okumura K, Kon K, et al. (2007) Role of adipocytokines in hepatic fibrogenesis. J Gastroentrol Hepatol 22, Suppl. 1, S87-S92.

31. Watanabe S, Yaginuma R, Ikejima K, et al. (2008) Liver diseases and metabolic syndrome. J Gastroenterol 43, 509-518.

32. Bertolani C \& Marra F (2008) The role of adipokines in liver fibrosis. Pathophysiology 15, 91-101.

33. Adachi M \& Brenner DA (2008) High molecular weight adiponectin inhibits proliferation of hepatic stellate cells via activation of adenosine monophosphate-activated protein kinase. Hepatology 47, 677-685.

34. Isoda K, Sawada S, Ayaori M, et al. (2005) Deficiency of interleukin-1 receptor antagonist deteriorates fatty liver and cholesterol metabolism in hypercholesterolemic mice. $\mathrm{J}$ Biol Chem 280, 7002-7009.

35. George J, Roulot D, Koteliansky VE, et al. (1999) In vivo inhibition of rat stellate cell activation by soluble transforming growth factor $\beta$ type II receptor: a potential new therapy for hepatic fibrosis. Proc Natl Acad Sci U S A 96, 12719-12724.

36. Bataller R \& Brenner DA (2005) Liver fibrosis. J Clin Invest 115, 209-218.
37. Gressner AM \& Weiskirchen R (2006) Modern pathogenetic concepts of liver fibrosis suggest stellate cells and TGF- $\beta$ as major players and therapeutic targets. J Cell Mol Med 10, 76-99.

38. Yoshiji H, Kuriyama S, Noguchi R, et al. (2006) Amelioration of liver fibrogenesis by dual inhibition of PDGF and TGF- $\beta$ with a combination of imatinib mesylate and ACE inhibitor in rats. Int J Mol Med 17, 899-904.

39. Moreira RK (2007) Hepatic stellate cells and liver fibrosis. Arch Pathol Lab Med 131, 1728-1734.

40. Leask A, Chen S, Pala S, et al. (2008) Regulation of CCN2 mRNA expression and promoter activity in activated hepatic stellate cells. J Cell Commun Signal 2, 49-56.

41. Borkham-Kamphorst E, Hermann J, Stoll D, et al. (2004) Dominant-negative soluble PDGF- $\beta$ receptor inhibits hepatic stellate cell activation and attenuates liver fibrosis. Lab Invest $\mathbf{8 4}$, 766-777.

42. Borkham-Kamphorst E, van Roeyen CRC, Ostendorf T, et al. (2007) Profibrogenic potential of PDGF-D in liver fibrosis. J Heptatol 46, 1064-1074.

43. Pinzani M, Gesualdo L, Sabbah GM, et al. (1989) Effects of platelet-derived growth factor and other polypeptide mitogens on DNA synthesis and growth of cultured rat liver fat-storing cells. J Clin Invest 84, 1786-1793.

44. Czochra P, Klopcic B, Meyer E, et al. (2006) Liver fibrosis induced by hepatic overexpression of PDGF-B in transgenic mice. J Hepatol 45, 419-428.

45. Vogelbruch M, Wellmann A, Maschek H, et al. (1995) Transforming growth factor $\beta 1$ in human liver tumors. Verh Dtsch Ges Pathol 79, 132-136.

46. Kondo F (2001) Benign nodular hepatocellular lesions caused by abnormal hepatic circulation: etiological analysis and introduction of new concept. J Gastroenterol Hepatol 16, 1319-1328.

47. Rangheard AS, Vilgrain V, Audet P, et al. (2002) Focal nodular hyperplasia inducing hepatic vein obstruction. AJR Am J Roentgenol 179, 759-762.

48. Makhlouf HR, Abdul-Al HM \& Goodman ZD (2005) Diagnosis of focal nodular hyperplasia of the liver by needle biopsy. Hum Pathol 36, 1210-1216.

49. Bioulac-Sage P, Laumonier H, Cubel G, et al. (2008) Overexpression of glutamine synthetase in focal nodular hyperplasia (part 1): early stages in the formation support the hypothesis of a focal hyper-arterialisation with venous (portal and hepatic) and biliary damage. Comp Hepatol (epublication 29 February 2008). 